\title{
IMPLIKASI TERBITNYA REGULASI TENTANG PERTIMAHAN TERHADAP DINAMIKA PERTAMBANGAN TIMAH INKONVENSIONAL DI PULAU BANGKA
}

\section{Citra Asmara Indra*}

\begin{abstract}
Implication of the publication of the regulation of dynamics of tin mining on Bangka Island, it is most clearly visible are the rise of tin mining unconventional. The Central Government controls over commodities lead is so strong that they use their hands to do military protection. The local community is prohibited to mine, sell, even save them even one kilogram of matter. This condition is a precondition for the emergence of dissharmonsation in the management of lead in this area. Last issue about the rules of tin mining this regulation until now has never been resolved. So in a forum, all conflicts that erupted about tin mining will stop when the tin islands of Bangka Belitung Province have been exhausted.
\end{abstract}

\section{Keywords :}

Regulation, Tin mining, Bangka Island

\section{PENDAHULUAN}

Dalam kurun waktu yang sangat lama, timah adalah komoditas yang tidak bisa disentuh bagi masyarakat lokal dalam berbagai bentuk. Kontrol Pemerintah Pusat atas komoditas timah begitu kuat sehingga mereka menggunakan tangan-tangan militer untuk melakukan proteksi sebagaimana dikatakan oleh (Erman, 2007: 230-231). Masyarakat lokal dilarang untuk menambang, menjual, bahkan menyimpannya walau satu kilogram pun. Kondisi ini menjadi prakondisi bagi munculnya disharmonisasi dalam pengelolaan timah di daerah ini.

*Penulis adalah Dosen pada Jurusan Sosiologi, Fakultas Ilmu Sosial dan Ilmu Politik, Universitas Bangka Belitung.
Perubahan frontal pun terjadi pada tahun 1998 dengan dikeluarkannya Kepmenperindag

Nomor 558/MPP/Kep/12/1998 tentang Ketentuan Umum di Bidang Ekspor yang tidak memuat timah sebagai barang yang diatur dan diawasi ekspornya. Keputusan ini tidak menempatkan komoditas timah sebagai komoditas strategis negara dan sebagai implikasinya timah kemudian menjadi barang bebas. Bebas karena Pemerintah Pusat tidak lagi menempatkannya sebagai komoditas yang seharusnya diatur dan diawasi ekspornya. Keputusan inilah sebetulnya yang paling awal menjadi pintu masuk bagi munculnya penambangan timah oleh masyarakat lokal secara langsung. 
Kepmenperindag 558/1998 dilakukan oleh masyarakat di Kepulauan tersebut kemudian disusul oleh Bangka Belitung ini dengan menambang Kepmenperindag Nomor 146/MPP/Kep/4/1999 yang melakukan timah secara inkonvensional atau dikenal revisi terhadap barang-barang strategis dengan sebutan Timah Inkonvensional negara dan lagi-lagi timah tidak masuk (TI). Timah Inkonvensional adalah aktivitas penambangan yang dilakukan dalam salah satu barang yang hendak diatur dan diawasi ekspornya. Pada tahun oleh sekelompok masyarakat ataupun perorangan diluar mitra kerja PT. Timah, yang sama, semangat desentralisasi kemudian mengalami penguatan seiring dengan munculnya UU Nomor 22 Tahun 1999 yang mengatur mengenai sistem pemerintahan daerah, disusul oleh UU Nomor 25 Tahun 1999 yang mengatur mengenai perimbangan keuangan pusat daerah. Dua UU tersebut menekankan mengenai kewenangan daerah, termasuk kewenangan untuk menerbitkan peraturan daerah.

Oleh karena timah telah menjadi barang bebas, sementara UU No. 22 Tahun 1999 mengatur bahwa segala urusan yang tidak diatur oleh pusat kemudian menjadi kewenangan daerah, maka Pemerintah Daerah, dalam hal ini Pemerintah Kabupaten Bangka pun segera merespon dengan menerbitkan Perda Nomor 6 Tahun 2001 yang intinya mengatur bahwa rakyat boleh melakukan penambangan (lihat juga Rahman, dkk, 2011: 30).

Apa yang terjadi kemudian dapat ditebak. Masyarakat kemudian berlombalomba melakukan penambangan dengan menggunakan berbagai cara. Aktivitas penambangan timah secara masal yang Tbk., dan PT. Koba Tin serta menggunakan mesin lebih dari 20PK (sebuah istilah penyebutan mesin untuk menggali timah, serta melakukan aktivitas penambangan di dalam atau di luar wilayah tambang yang telah ditetapkan oleh Pemerintah Daerah dalam Perda No. 6 Tahun 2001 tentang Peraturan Penambangan Timah). Selanjutnya dalam tulisan ini memakai istilah TI dipakai untuk menjelaskan segala bentuk aktivitas penambangan timah. Para pengusaha lokal menggunakan tenaga alat berat untuk mendapatkan timah, para pengusaha kelas menengah menggunakan alat-alat semprot, sementara para penambang kecil menggunakan tenaga manual dengan melimbang dan mengayak pasir-pasir timah. Ketiadaan regulasi pusat atas timah menyebabkan timah menjadi kontrol Pemerintah Daerah dan masyarakat secara langsung. Pemerintah Daerah memanfaatkan komoditas timah sebagai komoditas ekonomis dan politis, sementara masyarakat penambang memanfaatkan timah sebagai cara baru untuk masuk ke golongan ekonomi kelas atas. 


\section{PEMBAHASAN}

\subsection{Tarik Ulur Regulasi Antara} Pemerintah Pusat dan Pemerintah Daerah

Kontroversi tentang keluarnya Keputusan Menperindag No. 558/1998 itu sendiri dikarenakan tidak dicantumkannya Timah sebagai barang dagangan strategis, sedangkan selama ini sejak tahun 1967 timah selalu menjadi komoditas utama bagi Pemerintah Pusat. Berdasarkan barang yang diatur, diawasi serta dilarang ekspornya oleh pemerintah, merupakan suatu kebetulan yang 'aneh' ketika timah tidak termasuk di dalamnya, begitupun ketika berikutnya pemerintah menerbitkan Kepmenperindag No. 146/1999, timah lagi-lagi tidak termasuk ke dalam komoditas strategis sehingga kembali menjadi barang dagangan bebas dan secara kebetulan ketika Pemerintah Pusat kemudian mengeluarkan UU 22/1999 tentang Otonomi Daerah yang memberikan kekuasaan kepada daerah untuk mengelola timah secara penuh.

Pemerintah Daerah tentu saja merespon segera dengan mengeluarkan Perda 6/2001, sehingga secara berurutan dengan terbitnya Kepmenperindag, UU Otda dan Perda terlihat seperti menghadiahkan pengelolaan timah kepada Pemerintah Daerah dan aktor-aktor yang ikut bermain di dalamnya. Walaupun dalam perjalanannya Pemerintah Pusat mengeluarkan pelarangan ekspor pasir timah melalui KepMenperindag No. 443/MPP/Kep/2002 yang intinya melarang ekspor pasir timah, harus dicairkan terlebih dahulu dan tidak boleh diekspor dalam bentuk timah batangan. Bupati Bangka merespon keluarnya KepMenperindag tersebut dengan mengeluarkan SIPAD (Surat izin Perdagangan Antar Daerah melalui Perda No. 20/2003 yang bertujuan mengurangi penyelundupan pasir timah ke luar negeri.

Peluang penambangan timah inkonvensional pada dasarnya dibuka oleh dua regulasi utama, yakni Kepmenperindag Nomor 558/1998 dan UU Nomor 22 Tahun 1999 yang selanjutnya direspon oleh Pemerintah Daerah Kabupaten Bangka dengan menerbitkan Perda Nomor 6 Tahun 2001. Penambangan timah pada dasarnya melibatkan permainan relasi kuasa di tingkat elit atas dan elit bawah. Masyarakat penambang di tingkat akar rumput menjadi aktor di lini depan dan sekaligus merasakan dampak perubahan sosial yang paling nyata.

\subsection{Regulasi yang Mengatur Tentang} Pertimahan

\section{Undang-Undang No. 11 Tahun 1967}

Kendali Pemerintah Pusat atas timah yang dilakukan secara penuh pada masa Orde Baru, baik itu untuk dikelola oleh pertambangan timah maupun diserahkan kepada swasta ternyata tidak 
diimbangi dampaknya secara signifikan terhadap kondisi di daerah Bangka dan Belitung. Mekanisme sentralistik yang menjadi ciri khas pemerintah Orde Baru menjadi sebab awal permasalahan sistemik di Bangka Belitung. Dampak ekonomis pengelolaan timah pada masa Orde Baru membawa kekecewaan yang dalam terhadap penduduk dan pejabat daerah. Kondisi perlawanan ditampakkan tegas ketika Orde Baru tumbang melalui mekanisme yang memberikan celah bagi partisipasi daerah dan penduduk lokal untuk melakukan penambangan.

Pemerintahan Orde Baru memberlakukan UU No. 11/1967 tentang ketentuan-ketentuan pokok pertambangan. Timah sebagai komoditas strategis masuk dalam wilayah pengaturan negara. Dalih untuk kepentingan negara pada masa itu tidak menyebabkan resistensi di permukaan karena kebijakan Orde Baru adalah melakukan kontrol ketat atas pertimahan (Susilo \& Maemunah, 2009;53-55).

Erman (2007: 230-231) dalam bukunya mengatakan kontrol Pemerintah Pusat di Kepulauan Bangka Belitung ini sangat kuat pada masa Orde Baru dimana PT. Timah, Tbk menggunakan militer untuk memproteksi areal penambangan, melarang penduduk menambang timah, bahkan melarang penduduk menyimpan timah walau hanya $1 \mathrm{~kg}$ sekalipun, larangan keras memperdagangkannya, dan tentu saja kontrol Pemerintah Daerah bisa dikatakan sangat lemah atau hampir tidak ada sama sekali. Kepulauan Bangka Belitung terlebih pada Orde Baru hanyalah sebuah Daerah Tingkat II yang berada di wilayah Provinsi Sumatera Selatan. Persoalan ketidakadilan distribusi hasil kekayaan alam, yaitu timah yang ada di Provinsi Kepulauan Bangka Belitung tidak diprotes oleh masyarakat lokal sendiri karena Orde Baru menerapkan kebijakan sentralistis dan mementingkan stabilitas. Padahal arus kekayaan yang mengalir ke pusat dan Provinsi Sumatera Selatan pada saat itu begitu besar namun tidak diimbangi dengan perbaikan yang nyata bagi kehidupan masyarakat Kepulauan Bangka Belitung.

Situasi berbeda ketika masa awal berlakunya Otonomi Daerah. Ada desakan Pemerintah Daerah untuk memiliki saham PT. Timah, Tbk., tuntuan pengembalian bekas daerah penambangan, tuntutan pergantian direktur utama PT. Timah, Tbk., yang dijabat oleh orang Jawa kepada putra daerah, dan kritik-kritik mengenai transparansi manajemen perusahaan, serta anggapan ketidakpedulian PT. Timah, Tbk., terhadap kepentingan penduduk lokal (Erman, 2007: 231-233; Bangka Pos, 13/4/2011). Damanik (dalam Kompas 8/12/2001 sebagaimana dikutip Erman, 2007: 237-238) mengatakan bahwa menjamurnya TI sebenarnya tidak lepas dari faktor PT. Timah, Tbk., sendiri yaitu 
kurangnya kepedulian perusahaan terhadap masyarakat setempat, investasi keuntungan yang tidak berbasis kebutuhan lokal, tindakan keamanan perusahaan yang represif, dan kurang menjalin keharmonisan dengan pemerintah dan legislatif daerah.

Secara sederhana dapat dipahami bahwa pemanfaatan timah sebagai sumber ekonomi alternatif bagi masyarakat sebenarnya sudah berlangsung turuntemurun, namun monopoli hak pengelolaan oleh negara pada beberapa masa menyebabkan penambangan timah inkonvensional di daerah ini mudah ditelusuri penyebabnya. Sujitno (2007: 299) menyebut ini sebagai 'dendam sejarah' dimana otonomi daerah dipahami secara sederhana oleh sebagian anggota masyarakat sebagai hak lokal dalam mengelola timah di Provinsi Bangka Belitung.

2. Keluarnya Kepmenperindag No. 558/1998 dan UU No. 22/1999

Celah untuk melakukan praktik pertambangan di luar dua perusahaan, yaitu PT. Timah, Tbk., dan PT. Koba Tin terjadi ketika Menperindag mengeluarkan keputusan Nomor No. 558/MPP/Kep/12/1998 tentang Ketentuan Umum di Bidang Ekspor yang tidak memuat timah sebagai barang yang diatur dan diawasi ekspornya.
UU No. 22 Tahun 1999 membuka peluang bagi desentralisasi yang luas tentang perimbangan keuangan, menetapkan kewenangan otonomi kepada daerah, pemanfaatan kekayaan nasional secara adil dan perimbangan keuangan antara pusat dan daerah. Karena komoditas timah tidak diatur dalam tata niaga perdagangan, maka celah kausul UU No. 22 Tahun 1999 tentang Desentralisasi menjadi pintu masuk. Ketentuan ini mengatur bahwa segala yang tidak diatur oleh Pemerintah Pusat, maka kewenangannya menjadi milik daerah melalui mekanisme desentralisasi. Dengan keluarnya SK Menperindag tersebut, maka komoditas timah kini menjadi barang yang memungkinkan dikelola oleh daerah sepenuhnya.

\section{Peraturan Daerah No. 6 Tahun 2001}

Pemerintah Daerah Provinsi Kepulauan Bangka Belitung memberikan respon atas celah peraturan pertambangan timah yang diakibatkan munculnya Kepmenperindag 558/1998 dan UU 22/1999, maka terbitlah Perda No. 6 Tahun 2001 (lihat dalam lampiran), yaitu tentang Pengelolaan Pertambangan Umum dan tentang Tata Cara dan Prosedur Perizinan Usaha Pertambangan, kemudian diikuti dengan diterbitkannya SKEP (Surat Keputusan Edaran Pemerintah) Bupati Bangka (Rahman, dkk, 2011:29; Susilo\&Maemunah, 2009: 59). 
Dalam Perda ini mengatur dua jenis penambangan, yaitu pertama, penambangan yang berbadan hukum, seperti BUMN, BUMD, Perusahaan swasta dan Koperasi, kedua pertambangan rakyat. Baik penambang yang berbadan hukum maupun pertambangan rakyat dalam melakukan penambangan mengajukan izin kepada Bupati. Untuk yang berbadan hukum akan memperoleh IUP (Izin Usaha Pertambangan) sedangkan pertambangan rakyat akan mendapat IUPR (Izin Usaha Pertambangan Rakyat). Pertambangan rakyat diklasifikasikan atas dua, yaitu pertama, yang dikelola secara perorangan dan menggunakan peralatan sederhana dan non-mekanik, kedua, dikelola secara perorangan dengan menggunakan maksimal mesin berkekuatan $20 \mathrm{PK}$.

Kabupaten Bangka merupakan satu-satunya Kabupaten yang mengeluarkan beberapa peraturan tentang aturan perijinan menambang karena hingga saat ini dikarenakan pada masa dikeluarkannya Perda dan kebijakan Pemerintah Daerah Kabupaten Bangka Induk lainnya, Provinsi Kepulauan Bangka Belitung pada waktu itu belum otonomi serta menjadi provinsi terpisah dari Provinsi Sumatera Selatan sehingga otomatis belum ada daerah/kota lainnya yang dimekarkan, kecuali Kota Pangkal Pinang yang pada masa itu telah menjadi sebuak Kotamadya, baru kemudian pada tahun 2003 setelah menjadi Provinsi baru, yaitu Provinsi Kepulauan Bangka Belitung kemudian dimekarkan menjadi 3 kabupaten baru, khusus untuk Pulau Bangka saja, yaitu Kabupaten Bangka Tengah, Kabupaten Bangka Selatan dan Kabupaten Bangka Barat.

Dituturkan Rahman (2006: 3) bahwa sejak dikeluarkannya Perda No. 6/2001, masyarakat melakukan aktivitas penambangan secara bebas sampai kemudian muncul istilah TI atau Tambang Inkonvensional, masyarakat boleh melakukan penambangan dimana saja dan kapan saja tanpa batas. Maraknya penambang TI disebabkan oleh beberapa faktor, yaitu akibat terjadinya penurunan harga lada, sementara harga timah cukup tinggi sehingga banyak aggota masyarakat beralih mata pencaharian dari kegiatan sebagai petani ke bidang usaha penambangan timah yang secara ekonomi lebih banyak memberikan penambahan penghasilan. Faktor lainnya adalah jumlah angkatan kerja yang membutuhkan lapangan pekerjaan setiap tahun terus bertambah, dan umumnya mereka yang beralih profesi menjadi penambang TI karena kurang mempunyai daya saing dalam lapangan kerjasehingga menambang timah merupakan pilihan yang paling memungkinkan. Faktor berikutnya adalah investor dalam dan luar negeri yang berdatangan, diikuti dengan ribuan pekerja dari luar daerah. Sujitno mengatakan 
(2007: 290-296) dalam melakukan penggalian timah masyarakat menggunakan varian peralatan sederhana sampai berat, seperti tercatat pada tahun 2002 diperkirakan ada sekitar 3.000 buah alat berat Buldozer $(\mathrm{PC}=$ Produksi Caterpilar) yang beroperasi sehingga akibatnya eksplorasi timah secara besarbesaran yang melibatkan masyarakat luas memunculkan dampak besar bagi produksi PT. Timah, Tbk., dan PT. Koba Tin. Hasil tambang masyarakat dijual bebas kepada kolektor yang kemudian mengekspornya ke berbagai negara. Harga jual kepada para kolektor timah tersebut lebih mahal dibandingkan jika masyarakat, dalam hal ini para penambang, menjualnya kepada PT. Timah, Tbk., dan PT. Koba Tin. Celah perdagangan timah yang tidak diatur oleh negara menyebabkan arus ekspor timah ke luar negeri marak.

Pertambangan timah di Kepulauan Bangka Belitung sejak bergulirnya reformasi diwarnai oleh eksplorasi yang dilakukan berbagai pihak, yakni PT. Timah, Tbk., PT. Koba Tin, Tambang Inkonvensional baik skala besar, sedang maupun kecil, para pelimbang dan perusahaan-perusahaan swasta baik individu maupun patungan.

\subsection{Kondisi Pertimahan di Pulau} Bangka

\section{Kondisi Ekonomi}

Terbitnya Surat Keputusan Bupati Bangka No. 540.K/271/Tamben/2001 tentang Pemberian Usaha Pertambangan untuk Pengolahan dan Penjualan (ekspor) merupakan salah satu usaha Pemerintah Kabupaten Bangka dalam usaha untuk terus melegalkan usaha tambang Timah Inkonvensional. Keluarnya SKEP Bupati Bangka tersebut dan Perda No. 21/2001 tentang Pelaksanaan Pertambangan Umum di Bangka serta Perda No. 2/2001 tentang Pelaksanaan Peraturan Ekspor Pasir Timah Biasa merupakan respon atas terbitnya Kepmenperindag No. 294/MPP/Kep/10/2001 yang kembali tidak memuat tata niaga timah sebagai barang yang diatur, mengakibatkan tafsir atas timah yang awalnya adalah komoditas strategis menjadi barang bebas yang perdagangannya tidak diawasi. Menurut Bupati Bangka pada saat itu, Perda kemudian SKEP No. 540.K/271/Tamben/2001 tersebut dimaksudkan untuk meningkatkan Pendapatan Asli Daerah (Romli: 115).

Perda No. 6/2001 Bupati Bangka ini memberikan kesempatan kepada siapapun untuk melakukan penambangan, dan terutama untuk para pelaku usaha yang bergerak dalam bisnis perdagangan pasir timah ini yang pada dasarnya adalah terutama bekas pemilik Tambang Kontrak 
Karya yang semula terikat dengan PT. Timah, Tbk. Mereka umumnya adalah keturunan Cina, yang mendapat peluang mengekspor timah langsung ke luar Bangka sangat menguntungkan bagi mereka. Selain perbedaan harga yang tinggi, yang terpenting juga telah memotong jalur pemasaran timah yang hierarkis dan birokratis. Dalam hal ini perbedaan harga misalnya apabila mereka menjual pasir timah ke Singapura, maka perbedaannya bisa mencapai 24 ribu rupiah per kilogram. Selain itu juga persyaratan mengenai kualitas timah yang harus disetorkan ke PT. Timah, Tbk., sangat berat yaitu dengan kadar timah 72 SN, (Erman, 2007:235).

Alasan dari Keputusan Bupati Bangka tersebut bisa dimengerti disebabkan lesunya roda perekonomian di Provinsi Bangka Belitung dikarenakan turunnya harga lada secara drastis hingga mencapai 12 ribu per kilogram pada awal tahun 2003, sehingga dengan adanya Perda dan SKEP tersebut membawa angin segar bagi masyarakat yang secara instan bisa mendapatkan uang cash secara langsung berkebalikan apabila masih menjadi petani lada yang membutuhkan kesabaran luar biasa baru bisa panen.

Sebenarnya tidak ada data statistik yang cukup dipercaya mengenai jumlah TI di seluruh pulau Bangka, karena selain sebagai sebuah aktivitas ekonomi informal, pergerakan TI yang tinggi juga menyulitkan pihak PT. Timah, Tbk. maupun instansi terkait di daerah untuk mendata jumlah TI secara tepat. Diperkirakan pada tahun 2001, jumlah TI mencapai 6000 unit dan pada tahun 2004 lebih kurang meningkat $400 \%$ dari tahun sebelumnya. Sementara menurut data dari Asosiasi Tambang Timah Rakyat (Astira), jumlah TI justru kurang lebih mencapai 13.345 unit. Jika diakumulasikan dengan TI yang tidak terdaftar, diperkirakan total jumlah TI mencapai 18.000 unit (Susilo \& Maemunah, 2009 : 78).

Satu unit TI dioperasionalkan oleh 2-5 orang, tergantung besar kecilnya skala TI. Jika saja diasumsikan tiap TI dioperasionalkan rata-rata 3 orang, maka jumlah pekerja TI akan mencapai sekitar 54.000 orang. Estimasi ini belum termasuk para pekerja yang mengais di ujung operasional TI yang disebut dengan istilah pelimbang, termasuk di dalamnya adalah para perempuan dan anak-anak. Para pelimbang biasanya mengumpulkan lagi timah sisa operasional TI. Estimasi ini juga tidak menyertakan estimasi mengenai pelimbang yang menggunakan peralatan sederhana dengan cara menggali dan mengayak di pinggiran kolong atau sungai. Sebagaimana diharapkan Bupati Bangka dengan mengeluarkan Perda dan SKEP, hasil yang didapatkan membawa akibat positif terhadap Pendapatan Asli Daerah. Sumbangan begitu besar dari sektor pertimahan antara bulan Januari - 
September 2001 mencapai 9 miliar rupiah, dan angka ini jauh lebih besar dibanding sumbangan PT. Timah, Tbk.yang hanya 2 sampai 3 miliar per tahun ke Pemkab Bangka (Bangka Pos, 16/9/2003). Sedangkan di lain pihak, keberadaan TI dan perusahaan pengekspor timah merupakan pesaing baru bagi PT. Timah, Tbk, sebab produksi TI jauh lebih besar, karena mereka tidak hanya mengandalkan peralatan berat saja dengan alat sederhana pun mereka bisa menghasilkan timah dengan kualitas cukup baik. Dengan kondisi seperti itu, PT. Timah, Tbk., tidak lagi memonopoli penambangan dan perdagangan timah di Bangka Belitung, dan menyalahkan bahwa suplai TI yang berlebihan sebagai awal menurunnya harga timah di pasaran internasional (Ibrahim, 2011: 64).

Kondisi ini terus berlangsung dan mengakibatkan neraca keuangan PT. Timah, Tbk., berada dalam kondisi terburuk dalam sejarah sejak berdirinya perusahaan tersebut. Meskipun keberadaan TI bukanlah satu-satunya yang membawa PT. Timah, Tbk., di ambang kehancuran, para anggota DPRD I dan DPRD II dari dua partai besar, memberikan kritikan tajam dengan mengatakan bahwa terjadinya permainan elit kuasa antara Perda Bupati versus KepMenperindag sehingga dibentuklah Tim Sebelas yang terdiri dari para wakil dan pemerintah kabupaten, kotamadya, dan provinsi, serta
PT. Timah, Tbk., dan PT. Koba Tin menemui Menteri Dalam Negeri (Romli, 2007:100).

Hasil dari pertemuan tersebut adalah terbitnya KepMenperindag No. 443/MPP/Kep/2002 tentang Pelarangan Ekspor Timah dalam bentuk pasir timah dan terlebih dahulu harus dicairkan dan baru boleh di ekspor dalam bentuk batangan, selanjutnya para eksportir timah harus memiliki wilayah kuasa penambangan.

Terbitnya KepMerindag tersebut, telah memicu terjadinya resistensi tersebut, dikarenakan kalangan pengusaha paling keras bersuara yaitu Direktur Utama Perusahaan Daerah yang dimiliki oleh Pemkab Bangka (Romli, 2007:110), yaitu PT. Bangka Global Mandiri. Menurutnya, keputusan pencabutan ijin ekspor pasir timah tidaklah memberikan jalan keluar bagi pemecahan menyeluruh terhadap persoalan bisnis timah, sebab akan membawa keresahan bagi 11.000 penambang rakyat yang menggantungkan mata pencaharian mereka pada TI. Resistensi lainnya datang dari salah satu anggota DPRD tingkat I dari partai besar di Pronvinsi Kepulauan Bangka Belitung yang sekaligus pengusaha timah yang tidak lagi bermitra dengan PT. Timah, Tbk., yang menyayangkan keputusan larangan eksportir pasir timah tersebut. Perdebatan tentang Kepmenperindag tersebut telah menempatkan partai besar di level provinsi 
pada posisi yang berlawanan, satu partai besar mendukung keputusan Menteri Perdagangan dan Industri, dan satu partai besar lainnya yang merupakan kendaraan Bupati Bangka saat itu yang memprotes keputusan tersebut.

\section{Kondisi Sosial dan Lingkungan Fisik}

Tarik ulur regulasi masalah pertimahan yang tidak kunjung usai di level atas, antara Pemerintah Pusat dan Pemerintah Daerah serta di kalangan Pemerintah Daerah sendiri sehingga TI dengan segala permasalahannya terus berjalan. Dampak terhadap kondisi sosial lingkungan akibat penambangan timah yang dilakukan secara besar-besaran di berbagai daerah di Provinsi Kepulauan Bangka Belitung.

\section{Kerusakan}

lingkungan

dikarenakan merambahnya penambangan TI ke lokasi-lokasi terlarang untuk ditambang, seperti pantai, aliran sungai, hutan lindung, kebun, bahkan halaman rumah sendiri untuk digali. Para nelayan kehilangan mata pencaharian, karena tidak memperoleh ikan tangkapan, daerah tangkapan mereka sudah dikotori oleh TI Apung, pengusaha jasa seperti hotel-hotel yang diharapkan mampu meningkatkan PAD, mengeluh karena pantai-pantai yang dijadikan objek wisata menjadi kotor dan tercemar bahkan banyak pantai yang hilang karena tergerus mesin TI. Penduduk desa mengeluh karena langkanya air bersih di sungai-sungai, air sungai menjadi kotor tercemar solar yang dihasilkan mesin TI, penduduk mengeluh pencemaran pengairan sawah, pemilik perkebunan dirugikan karena sebagian lahan mereka telah berubah menjadi kolong-klong kecil bekas galian TI. Kondisi seperti ini hanya sebagian kecil permasalahan lingkungan yang muncul akibat keberadaan TI.

Terjadi pergeseran tajam dalam pola perilaku masyarakat. Seiring dengan masuknya para pekerja luar daerah, dampak sosial yang ditimbulkan menjadi beragam. Situasi ini senada dengan pendapat Keraf (2010:86) bahwa kehancuran sumber daya alam dan keanekaragaman hayati membawa pengaruh langsung bagi kehancuran budaya masyarakat setempat. Degradasi moral dan mental tidak sebanding dengan laju ekonomi masyarakat (Wahab, 2011:18). Masalah minuman keras, judi dan pelacuran hal yang tidak terelakkan, menampakkan gejala yang sama pada masa penggalian zaman kolonial (Erman, 2007 : 260; Yunianto, 2009 : 102).

Praktik TI juga berdampak pada perubahan perilaku masyarakat yang semula berkultur petani yang sabar, menjadi masyarakat konsumtif dan agresif. Begitu juga dengan dampaknya bagi anakanak yang cenderung mengabaikan pendidikannya, tertarik menambang karena bisa menghasilkan uang secara instan dan 
cepat (Sujitno, 2007 : 296; Febriani, 2011 : 33-37).

Pertambangan timah oleh masyarakat juga telah menggeser budaya menanam padi masyarakat yang dulunya menjadi salah satu alternatif mata pencaharian penduduk secara periodik dan membantu suplai kebutuhan akan beras (Bangka Pos 25/2/2011). Ketika timah tidak lagi menjadi primadona, para pencari kerja yang mulanya mencari rejeki dengan menambang kehilangan pekerjaan. Apalagi diprediksi banyak kalangan menyebutkan bahwa cadangan timah Bangka Belitung akan segera habis dalam beberapa tahun ke depan. Kemungkinan akan terjadinya kekerasan atau kekacauan sangat potensial terjadi mengingat selama ini penambangan timah bersifat terbuka dan bebas, para pencari kerja datang dari berbagai penjuru yang umumnya kemudian menetap atau menikah dengan penduduk lokal.

Simpul Walhi Babel (Kompas 17/5/2010) menyatakan rata-rata tiap minggu 4-5 jiwa melayang akibat penambangan inkonvensional yang tidak mempertimbangkan keselamatan kerja. Itu semua merupakan dampak sosial lainnya dari penambangan timah inkonvensional, kematian karena tidak dibekali dengan pengetahuan serta alat yang memadai tentang keselamatan kerja dalam menambang. Seperti dituturkan oleh Erman (2007;262), penambang tertimbun pasir, galian yang runtuh, kehabisan oksigen, terjepit mesin dan tidak adanya jaminan sosial adalah deretan cerita yang lazim terjadi dalam kehidupan para penambang. Meski demikian, keinginan untuk mendapatkan uang secara instan dan kontan dalam jumlah besar seperti candu, sementara korban dari penambang terus berjatuhan, para pengusaha terus menarik keuntungan.

\section{PENUTUP}

Implikasi dari terbitnya regulasi tentang pertimahan terhadap dinamika pertambangan timah di Pulau Bangka, hal yang paling jelas terlihat adalah maraknya penambangan Timah Inkonvensional. Pada level daerah, Pemerintah Daerah Kabupaten Bangka merespon terbitnya regulasi yang tidak mengatur tentang timah sebagai bahan strategis milik negara yang dilarang untuk diekspor dengan menerbitkan Perda No. 6/2001 dengan terbitnya Perda tersebut memberikan akses kepada masyarakat di seluruh lapisan untuk menggali timah, walaupun secara jelas bagaimana aturan dalam menambang timah secara legal, tetapi masyarakat menafsirkan perda tersebut sebagai dasar hukum untuk melakukan penambangan illegal dijadikan legal dengan sebutan menambang timah secara inkonvensional.

Tarik ulur antara Pemerintah Pusat, Pemerintah Daerah serta aktor-aktor yang bermain di dalamnya sangat 
berpengaruh pada perubahan-perubahan yang terjadi dengan terbitnya beberapa regulasi yang mengatur tentang pertimahan. Terlihat seperti adanya regulasi tandingan yang diterbitkan oleh Pemerintah Pusat dan Pemerintah Daerah. Pemerintah Pusat menggunakan wewenangnya dengan mengeluarkan Kepmenrindag No. 558/1998 dan UU No. 22/1999 diikuti dengan KepMenperindag 146/MPP/Kep/4/1999 sekali lagi tidak mencantumkan timah sebagai barang strategis negara yang dilarang untuk diekspor, seakan memberikan hadiah kepada Pemerintah Daerah berupa kesempatan yang seluas-luasnya untuk menggali potensi timah yang selama ini dimonopoli oleh PT. Timah, Tbk., dan Pt. Koba Tin. Ditanggapi dengan hangat oleh Pemerintah Daerah dengan menerbitkan Perda No.6/2001 dan beberapa Perda lainnya untuk melegalkan usaha penambangan timah di Pulau Bangka dan Belitung. Para aktor yang terlibat jelas mempunyai kepentingan ekonomi yang sangat besar, serta para birokrat yang dengan dalih melindungi pulau Bangka dari kehancuran sesungguhnya penuh dengan muatan politis untuk memenangkan hati rakyat dalam pemilihan kepala daerah periode selanjutnya.

\footnotetext{
Peliknya permasalahan tentang aturan yang benar tentang regulasi pertimahan ini sampai sekarang tidak pernah terselesaikan. Sehingga dalam
}

suatu forum tercetus bahwa, semua konflik tentang pertimahan akan berhenti ketika suatu saat timah di Provinsi Kepulauan Bangka Belitung ini telah habis. Pada level umum bagaimana kemudian syarat-syarat penambangan dalam Perda tersebut berlaku untuk para pemilik modal besar, sedangkan bagi masyarakat yang berani membuka lahan untuk ber - TI dengan modal seadanya sesungguhnya buta terhadap ada atau tidaknya regulasi yang mengatur tentang penambangan timah secara legal maupun illegal.

Pemerintah Daerah Kabupaten Bangka khususnya dalam menghadapai krisis ekonomi, harus bekerja keras mencari jalan keluar atau alternatif bidang pekerjaan lain pasca timah. Pemberdayaan sumber daya alam selain timah perlu lebih ditingkatkan, misalnya sektor pariwisata dan sekiranya setiap peluang untuk mendatangkan investor dan wisatawan ke dalam daerah dikelola dengan serius. Peningkatan sarana dan prasarana pendidikan bagi masyarakat yang tinggal di daerah-daerah penambangan dan adanya suatu usaha untuk menarik kembali anakanak yang sempat putus sekolah karena tergiur untuk menambang TI agar mau bersekolah lagi.

Pemerintah Daerah hendaknya lebih memusatkan perhatian dengan menggalakkan kembali budaya berkebun dan bertani dalam rangka investasi jangka panjang, terutama bagi para penambang 
yang tadinya adalah para petani lada dan karet. Penyediaan bibit serta kemudahan bagi mereka yang mau berkebun kembali untuk mendapatkan bibit lada maupun tanaman palawija lainnya, serta koordinasi yang baik antara Pemerintah Pusat dan Pemerintah Daerah dalam perihal memasarkan hasil perkebunan tersebut disertai dengan jaminan harga yang sesuai sehingga para petani tidak selalu menjadi pihak yang dirugikan dan menjadi motivasi mereka untuk terus bertani dan memaksimalkan hasil perkebunan mereka sehingga kualitas hasilnya tidak kalah dengan pasar domestik maupun ekspor.

\section{DAFTAR PUSTAKA}

Damsar, 1997. Sosiologi Ekonomi, Jakarta : RajaGrafindo Persada.

Distamben Provinsi Kepulauan Bangka Belitung, 2003. Prospek Pengembangan Pertambangan dan Energi di Provinsi Kepulauan Bangka Belitung, Pangkalpinang : Distamben Provinsi Kepulauan Bangka Belitung.

Dua, Mikhael, 2008. Filsafat Ekonomi Upaya Mencari Kesejahteraan Bersama, Yogyakarta : Kanisius.

Erman, Erwiza, 2007. Deregulasi Tata Niaga Timah dan Pembuatan Negara Bayangan Lokal: Studi Kasus Bangka dalam Politik Lokal di Indonesia, editor: Henk Schulte Nordholt dan Gery van Klinken dibantu oleh Ireen KarangHoogenboom, Jakarta : Yayasan Obor Indonesia-KITLV.

2009. Dari Pembentukan Kampung ke Perkara Gelap,
Menguak Sejarah Timah di Bangka Belitung, Yogyakarta : Ombak.

Febriani, Luna, 2011. Pudarnya Pesona 'Muntok White Pepper' (Refleksi untuk Mengembalikan Kejayaan Lada) dalam Sekaput Ancup of Bangka Belitung, Yogyakarta : Penerbit Khomza bekerjasama dengan Ilalang Institute.

Garvey, James, 2010. Karya Filsafat Terbesar, diterjemahkan oleh CB. Mulyatno Yogyakarta : Pr., Kanisius.

Giddens, Anthony, 2007. Kapitalisme dan Teori Sosial Modern, Suatu Analisis terhadap Karya-Tulis Marx, Durkheim, dan Max Weber, diterjemahkan oleh Soeheba Kramadibrata, Jakarta : UI-Press.

Harliyana, 2008. Pengaruh Penambangan Timah Rakyat Terhadap Perubahan Fisik Lingkungan dan Sosial Ekonomi Masyarakat di Kecamatan Pemali Kab. Bangka, Tesis, Tidak diterbitkan, Yogyakarta : Universitas Gadjah Mada.

Haryadi, Dwi, 2011. Potret Hukum di Babel dalam Sekaput Ancup of Bangka Belitung, Yogyakarta : Penerbit Khomza bekerjasama dengan Ilalang Institude.

Holimin, 2003. Peranan Industri Penambangan Timah dalam Dinamika Perubahan Sosial dan Implikasinya Terhadap Ketahanan Wilayah (Studi di PT. Timah, Tbk., Kab. Bangka), Tesis, Tidak diterbitkan, yogyakarta : Universitas Gadjah Mada.

Ibrahim, 2011. Pertimahan Dalam Perspektif Ekonomi Pancasila (Studi Kasus di Provinsi Kepulauan Bangka Belitung), Desertasi, Yogyakarta : Tidak diterbitkan, Universitas Gadjah Mada. 2002. Kepulauan Bangka Belitung Menuju Hakikat Sebuah Propinsi, Yogyakarta : Pustaka Selawang 
Sedulang bekerjasama dengan Philosophy Press.

Kartono, Kartini, 1996. Pengantar Riset Sosial, Bandung : Mandar Maju.

Keraf, A. Sonny, 2010. Krisis dan Bencana Lingkungan Hidup Global, Yogyakarta : Kanisius.

Macionis, J. John, 1987. Sociology, Prentice Hall, Ney York : Englewoods Cliff.

Monografi Kelurahan Desa Lampur, 2010. Profil Desa Lampur, Daftar Isisan, Data Dasar Profil Desa, Kecamatan Sungai Selan, Kabupaten Bangka Tengah, Provinsi Kepulauan Bangka Belitung, Lampur : Monografi Kelurahan Desa Lampur.

Poerwandari, E. Kristi, Pendekatan Kualitatif, Perpustakaan Unika Atma Jaya, LPSP3, Jakarta : FP-UI.

Rahardjo, Mudjia, 2007, Sosiologi Pedesaan (Studi Perubahan Sosial), Malang : UIN-Malang Press.

Rahman, Bustami, dkk, 2011. Menyoal Pertimahan di Babel (Beberapa Cerita dan Gagasan), Yogyakarta : Penerbit Khomza.

Rawls, John, 2006. Teori Keadilan, Dasardasar Filsafat Politik untuk Mewujudkan Kesejahteraan Sosial dalam Negara diterjemahkan oleh Uzair Fauzan dan Heru Prasetyo, Yogyakarta : Pustaka Pelajar.

Rizter, Goerge \& Goodman, J. Douglas, 2011. Teori Marxis dengan Berbagai Ragam Teori NeoMarxian, diterjemahkan oleh Nurhadi, Bantul : Kreasi Wacana.

Romli, Lili, 2007. Potret Otonomi Daerah dan Wakil Rakyat di Tingkat Lokal, Yogyakarta : Pustaka Pelajar.

Soemardjan, Selo, 2009. Perubahan Sosial di Yogyakarta, Yogyakarta : Komunitas Bambu Depok.

Sujitno, Sutedja, 2007. Dampak Kehadiran Timah Indonesia Sepanjang
Sejarah, Jakarta : PT. Gramedia Pustaka Utama.

Sulistiany, Ambar, 1999. Rambu-rambu Jurnalistik, Yogyakarta : Pustaka Pelajar.

Susilo, Joko \& Siti Maemunah, 2009. Tiga Abad Melayani Dunia, Potret Tambang Timah Bangka Belitung, Jakarta : Jaringan Advokasi Tambang (JATAM).

Triadhi, Joko, 2005. Analisis Dampak Kegiatan TI di Lingkungan Kabupaten Bangka Tengah, Provinsi Kepulauan Bangka Belitung, Tesis, Yogyakarta : Tidak diterbitkan, Universitas Gadjah Mada.

Wahab, Hendra Rani, 2011. Babel dan Krisis Ekologi dalam Sekaput Ancup of Bangka Belitung, Yogyakarta : Penerbit Khomza bekerjasama dengan Ilalang Institude.

Weber, Max, 2006. Sosiologi, diterjemahkan oleh Noorkholis dan Tim Penerjemah Promothea, Yogyakarta : Pustaka Pelajar.

Yin, K. Robert, 2003. Metode Penelitian Studi Kasus, Jakarta : RajaGrafindo.

Artikel, Jurnal, Laporan Penelitian, Makalah-Makalah, Bahan Presentasi

Batubara, Marwan, 2009. Ironi Tambang Timah di Babel, disampaikan pada Focus Group Discussion Pangkalpinang : Universitas Bangka Belitung 25 Juni 2009.

Erman, Erwiza, 2010. Politik Protes dan Etnisitas: Kasus Buruh Cina di Tambang Timah di Bangka-Belitung (1920-1950), dalam Jurnal Masyarakat Indonesia, Majalah Ilmu-Ilmu Sosial Indonesia, Jakarta : LIPI.

Ibrahim, 2005. Ayo, Terus Melimbang Timah!, Pangkalpinang : Artikel di Harian Bangka Pos 6 Oktober 2005. 
2006. Ghost City, Pangkalpinang : Artikel di Harian Bangka Pos 18 April 2006. , 2006. Dinamika Otonomi Daerah di Provinsi Kepulauan Bangka Belitung (Sebuah Otokritik), Bangka : disampaikan pada Diskusi Panel Komisi Ombudsman Daerah Bangka Belitung 20 Desember 2006.

Rahman, Rusli, 2006. Timah dan Politik, Jalan Tengah Mensejahterakan Rakyat, Pangkalpinang : disampaikan pada Diskusi Terbuka Konfercab XXI HMI Cabang Bangka Belitung 2 Desember 2006.

\begin{tabular}{cc}
$2006 . \quad$ Menyelamatkan \\
\hline Industri & Timah Nasional \\
disampaikan sebagai bahan diskusi.
\end{tabular}

Yunianto, Bambang, 2009. Kajian Problema Pertambangan Timah di Provinsi Kepulauan Bangka Belitung sebagai Masukan Kebijakan Pertimahan Nasional, Jurnal Teknologi Mineral dan Batubara Vol. 5, No. 3, Juli 2009.

\section{Dokumen Lainnya}

UU Nomor 11 Tahun 1967 tentang Ketentuan-Ketentuan Pokok Pertambangan.

UU Nomor 27 Tahun 1980 tentang Pengolahan Bahan-Bahan Galian.

Keputusan Menperindag Nomor 558/MPP/Kep/12/1998 tentang Ketentuan Umum di Bidang Ekspor.

UU Nomor 22 Tahun 1999 tentang Pemerintahan Daerah.

UU Nomor 25 Tahun 1999 tentang Perimbangan Keuangan Antara Pemerintah Pusat dan Daerah.

Keputusan Menperindag Nomor 146/MPP/Kep/4/1999 Perubahan Lampiran Keputusan Menteri Perindustrian dan Perdagangan Nomor $\quad 558 / \mathrm{MPP} / \mathrm{Kep} / 12 / 1998$ tentang Ketentuan Umum di Bidang Ekspor.

UU Nomor 27 Tahun 2000 tentang Pembentukan Provinsi Kepulauan Bangka Belitung

Perda Bupati Bangka Nomor 6 Tahun 2001 tentang Pengelolaan Pertambangan Umum.

SKEP Bupati Bangka Nomor 6 Tahun 2001 tentang Tata Cara dan Prosedur Perizinan Usaha Pertambangan.

Perda Bupati Bangka Nomor 20 Tahun 2001 tentang Penetapan dan Pengaturan Tatalaksana Perdagangan Barang Strategis.

Perda Bupati Bangka Nomor 21 Tahun 2001 tentang Pajak Pertambangan Umum dan Mineral Ikutan lainnya.

Keputusan Menperindag Nomor 294/MPP/Kep/10/2001 tentang

Pencabutan Keputusan Menteri Perindustrian dan Perdagangan Nomor. 146/MPP/Kep/4/1999 dan Penetapan Barang yang Diatur, Diawasi, dan Dilarang Ekspornya.

SKEP Bupati Bangka Nomor 540.K/271/Tamben/2001 tentang Pemberian Izin Usaha Pertambangan untuk Pengolahan dan Penjualan.

Keputusan Direktur Jendral Perdagangan Luar Negeri Nomor 02/DJPLN/KP/II/2002 tentang Tata Cara dan Persyaratan Ekspor Biji Timah.

Surat Izin Perdagangan Antar Daerah (SIPAD) melalui Perda Nomor 23 Tahun 2003.

Laporan Bank Indonesia Cabang Palembang Mengenai Perkembangan Ekonomi dan Perbankan Kepulauan Bangka Belitung Tahun 2006.

Kepulauan Bangka Belitung dalam Angka Tahun 2009, Biro Pusat Statistik 
Provinsi Kepulauan Bangka

Belitung.

UU Nomor 32 Tahun 2009 tentang Perlindungan dan Pengelolaan Lingkungan Hidup.

Laporan Capaian Kinerja Kegiatan (Pengendalian Keamanan Lingkungan) Tahun $2010 \quad \& 2011$ Dinas Satuan Polisi Pamong Praja Kabupaten Bangka Tengah.

\section{Surat Kabar}

Kompas, 8 Desember 2001, 4 Februari 2011, 16 Juni 2012.

Bangka Pos, 16 Sepetember 2003, 21 Februari 2004, 29 Oktober 207, 14 Maret 2009, 25 Februari 2011, 13 April 2011.

Rakyat Pos, 14 November 2008, 26 November 2008 